\title{
Age at First Birth in Uttar Pradesh: How Much Has It Actually Changed? Over Inter-NFHS Period?
}

\author{
Ajay Pandey ${ }^{1}$, Richa Sharma ${ }^{2}$ \\ ${ }^{1}$ Assistant Director, Population Research Centre, University of Lucknow, India \\ ${ }^{2}$ Deputy Director, National Institute for Labour Economics Research \& Development, Delhi, India \\ Correspondence: Assistant Director, Population Research Centre, University of Lucknow, India
}

Received: July 14, 2021 Accepted: December 12, 2021 Online Published: December 30, 2021

doi:10.5539/ijsp.v11n1p54 URL: https://doi.org/10.5539/ijsp.v11n1p54

\begin{abstract}
Culturally, there is always pressure among newly-wed to conceive early and have births in India. Previous studies have documented relationship between age at first birth \& fertility, besides the socio-demographic factors that influence age at first birth. The current study aims answering directions and quantum of such relationships using frailty models. The successive rounds of NFHS data (1, 2, 3 \& 4) from Uttar Pradesh is used in the study. Fertility in India is characterized as too-early-too-fast. By age-30 majority women would have completed the childbearing. However, the data from NFHS-4 shows some striking changes in the initiation of child bearing in Uttar Pradesh breaking away from the stereotypes of too early too fast characterization. While 44.67 percent of the women aged 30-34 had experienced first birth by age 18 in the year 1992-93 (NFHS-1), the percentages declined during 2015-16 (NFHS-4) to 28.25\%. However, by ages 26 majority of women (>95\%) aged 30-34 have had experienced first birth. Births at younger age are also a reflection on enforcement of child-marriage restraint act $\&$ adherence to legal minimum age at marriage which is 18 for girls \& 21 for boys. The data from NFHS-4 have some quality issues. Women aged as low as 5 have shown to have experienced first birth by that age. This may not be possible. The Kaplan Meier survival Graph provided the survival probabilities with respect of each predictor sub groups. The log rank test was used to test the equality of survivor function for each sub group of the predictor variable. The survivor function was significantly different among sub groups of the predictor variables except for the categories of ever use of contraception at NFHS1 and categories of religion across rounds of NFHS data. The Cox Proportional Hazards model was used to study the risk of first birth by socio demographic characteristics. The Frailty model capturing the unobserved heterogeneity in the event time was preferred over standard survival model. For the current study, gamma frailty with Weibull-hazard is used as it fits the data well. Age at marriage and women's literacy significantly determines the Age at First Birth. The inverse relationship with regard to ever use of contraception needs further analysis. The model also predicts significant frailty with variance parameter (theta) greater than one across the NFHS datasets.
\end{abstract}

Keywords: age at first birth, frailty models, cox proportional hazards model

\section{Introduction}

The age at first birth has important consequences on the demographic characteristic of the population. Lower age at first birth implies higher rate of fertility and population growth. Lower age at first birth increases the health hazards both for the mother and child. Early child bearing stymies growth and negatively impacts mother's educational attainment. This results in mothers reduced economic opportunity and labour market participation. Studies have shown strong relationship between age at first birth and total children ever born. Early childbearing also results in large number of children compared to those who start late. In developed economies, postponement of first births due to an increase in the age at marriage has contributed greatly to the decline in total fertility rate.

Uttar Pradesh traditionally had higher fertility compared to other States in India. The current fertility level in Uttar Pradesh is 2.7 children per women NFHS-4 (2015-16). Culturally it is expected from newlywed to bear children and initiate child bearing immediately after marriage. Not able to produce children immediately after marriage is perceived as women being in-fecund, negatively impacting women household social standing. Child Marriage Restraint Act promulgated by the Government of India has legislated legal minimum age at marriage of 21 years for boys and 18 years for girls, in-spite large proportion of them marry below the legal minimum. Lower age at marriage leads to teenage pregnancy and birth in-turn higher fertility.

This study aims to revisit the strength of association between age at first birth and socio-demographic factors in light of 
frailty models. The study will also examine the shift in age at first birth in Uttar Pradesh during the inter NFHS period from $1992-93$ to $2015-16$.

\section{Review}

The age of women at which they have first children has important consequences on the demographic characteristic of the population (Rajaretnam, 1990). Lower the age at first birth implies higher rate of fertility and population growth because of the shorter length of time between generations (Teachman, \& Heckert, 1985). Teenage pregnancies and birth are substantial health risks both for the mother and the child (Zabin, \& Kiragu, 1998). Adolescent child-bearing arrests mother's educational attainment growth resulting in reduced economic opportunity and participation in labour market for the mother as-well-as the household (Rao, \& Balakrishnan, 1988). There is a strong relationship between age at first birth and total children ever born to women. Early childbearing results in large number of children compared to those who start late (Bumpass, Rindfuss, \& Janosik, 1978; Rao, \& Balakrishnan, 1988). Early initiation of childbearing lengthens the reproductive period and subsequently increases fertility. In developed economies, postponement of first births-due to an increase in the age at marriage, has contributed greatly to overall fertility decline.

\section{Data \& Method}

The study utilizes the data from India's four rounds of National Family Health Survey conducted by Macro International and International Institute of Population Sciences under the auspices of Ministry of Health and Family Welfare, Government of India. The survey covered a wide range of data regarding demography and health of individual women and children. Complete reproductive history including fertility and health status of the individual women aged 10-49 were collected. From the raw data set cohort of married women aged 30-34 years was selected for the analysis, as by this age woman gets married eventually and experiences the child bearing event. A sample of women belonging to this cohort is analyzed. The sample consists of 1755 women from NFHS-1 (1992-93) (IIPS, 1995), 1486 women from NFHS-2 (1998-99) (IIPS, 2000), 1641 women from NFHS-3 (2005-06) (IIPS, 2007) \& 11,699 women from NFHS-4 (2015-16) (IIPS, 2017) belonging to the age cohort 30-34 years. Age of women at the time of first birth is considered as dependent variable. Frailty models with survival time data using parametric Cox Hazards Model is used in the analysis. In the analysis age at first birth episodes are assumed to follows Weibull distribution with gamma frailty. For details on frailty model one can refer to Wienke, 2011.

Dependent variable: Age at first birth is the dependent variable and it ranges between ages 5 to 34 .

The dependent (outcome) variable under the survival setting is Yi = Age of women at first birth. The independent variables/covariates used in the analysis are indicated below

$\mathrm{X} 1$ : Women's age at first marriage

$\mathrm{X} 2$ : Place of residence

$\mathrm{X} 3$ : Caste

X4: Religion

$\mathrm{X} 5$ : Educational status of women

X6 : Contraceptive ever use

\section{Objectives}

The specific objectives under the study are;

- To assess the direction and strength of association between age at first birth and selected socio-demographic factors using Cox Proportional Hazards model.

- To study the unobserved heterogeneity in the data using frailty models with baseline hazard function following Weibull distribution and Gamma frailty.

\section{Findings \& Discussion}

The study uses four successive rounds of NFHS data. The sample consists of 1755 (NFHS-1) 1486 (NFHS-2), 1641(NFHS-3) \& 11,699 (NFHS-4) women belonging to age cohort 30-34. The age at first birth distribution is shown in the figure-1 below. There has been marked shift in the median age at first birth from NFHS-1 to NFHS-4. NFHS-4 data in the figure shows large proportion of women experiencing child bearing at latter ages compared to NFHS-1. The NFHS-1 data shows $44.67 \%$ women experienced age at first birth by age 18 compared to $55.92 \%$ in NFHS-2, 45.17\% in NFHS-3 and $28.5 \%$ in NFHS-4.

The median age at first birth increased from 19 years in NFHS-1 to 20 years in NFHS-4. The Median age at first marriage increased from 16.0 years to 18.0 years during the same inter NFHS period, for women aged 30-34. The gap 
between median age at first birth and median age at marriage declined from 3 years in NFHS-1 to 2 years in NFHS-4. This indicates, though median age at first birth has increased in NFHS-4 and large proportion of women are experiencing age at first birth at latter years, they are experiencing first child after marriage faster compared to NFHS-1. This may also be a reflection on the declining custom of return marriages (Gauna) which was prevalent in Uttar Pradesh at the time of NFHS-1.

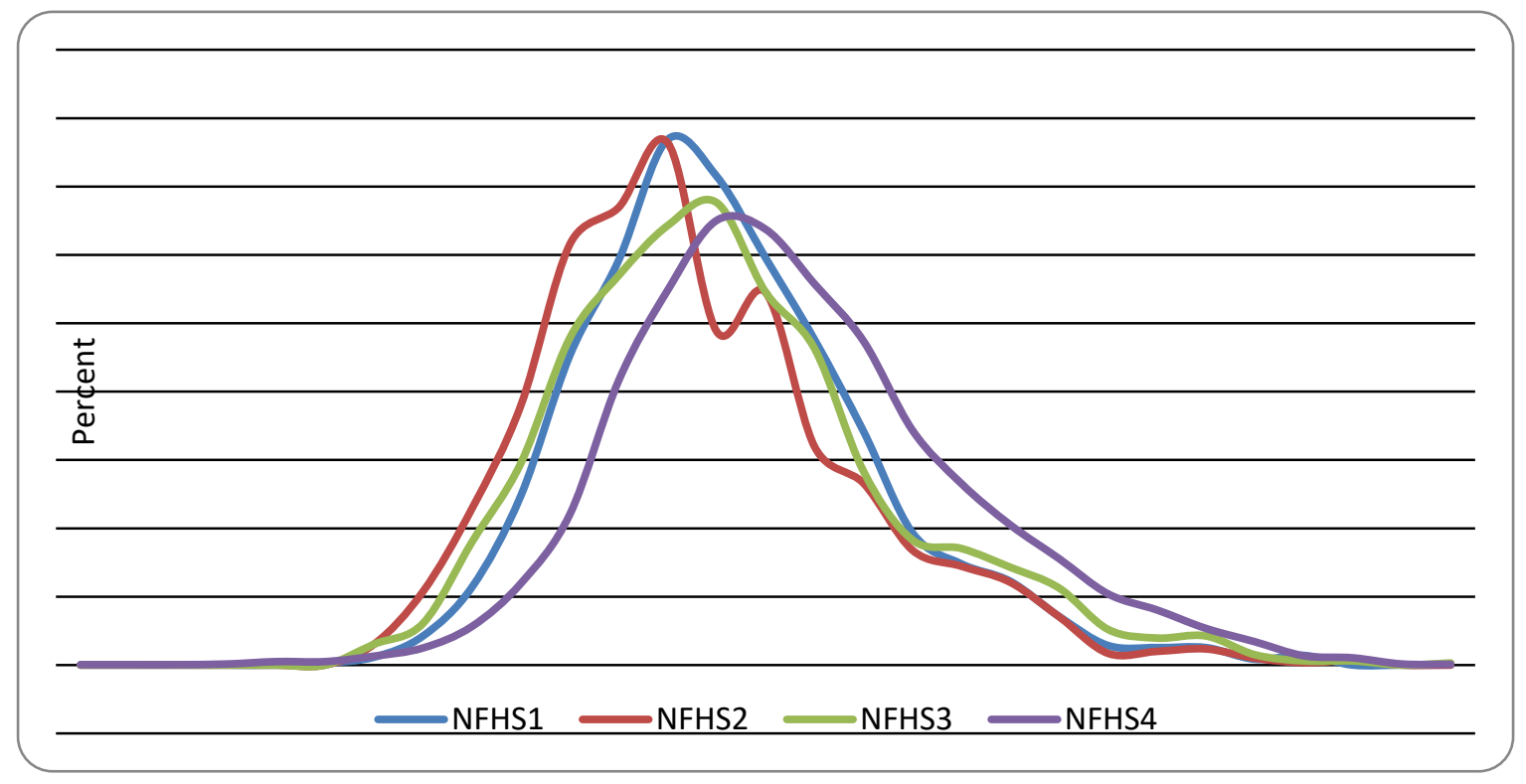

Figure 1. Age at First Birth: Uttar Pradesh

Table 1 below presents the mean and median duration of age at first birth by selected backgound charectristics. The table shows that the mean \& meidan duration has increased increased across categories over inter NFHS period. The mean \& median duration is higher for those whoes place of residence is urban who are urban residence, belong to other caste, are Hindus and are literate. With regard to ever use of contraception category, the mean and median duration are higher in NFHS-1 \& 3, while the mean and median duration is lower in case of NFHS-2 \& 4 .

Table 1. Mean and Median duration by selected background characteristics: NFHS-1 to NFHS-4

\begin{tabular}{|c|c|c|c|c|c|c|c|c|}
\hline & \multicolumn{2}{|c|}{ NFHS-1 } & \multicolumn{2}{|c|}{ NFHS-2 } & \multicolumn{2}{|c|}{ NFHS-3 } & \multicolumn{2}{|c|}{ NFHS-4 } \\
\hline & Mean & Median & Mean & Median & Mean & Median & Mean & Median \\
\hline Age at Marriage & 16.74 & 16.0 & 16.20 & 16.0 & 17.27 & 17.0 & 17.98 & 18.0 \\
\hline \multicolumn{9}{|c|}{ Place of residence } \\
\hline Rural & 18.4 & 18.0 & 18.56 & 18.0 & 18.51 & 18.0 & 20.28 & 20.0 \\
\hline Urban & 19.78 & 20.0 & 20.06 & 19.0 & 20.28 & 20.0 & 21.32 & 21.0 \\
\hline \multicolumn{9}{|l|}{ Religion } \\
\hline Hindu & 18.77 & 19.0 & 18.95 & 18.0 & 19.24 & 19.0 & 20.55 & 20.0 \\
\hline Other & 18.60 & 19.0 & 18.54 & 18.0 & 19.28 & 19.0 & 20.63 & 20.0 \\
\hline \multicolumn{9}{|l|}{ Caste } \\
\hline $\mathrm{SC} / \mathrm{ST}$ & 18.46 & 18.0 & 18.13 & 18.0 & 18.02 & 18.0 & 20.06 & 20.0 \\
\hline Others & 18.80 & 19.0 & 19.16 & 18.0 & 19.61 & 19.0 & 20.71 & 20.0 \\
\hline \multicolumn{9}{|l|}{ Education } \\
\hline Illiterate & 18.41 & 18.0 & 18.36 & 18.0 & 18.14 & 18.0 & 19.87 & 20.0 \\
\hline Literate & 19.74 & 20.0 & 19.96 & 20.0 & 20.84 & 20.0 & 21.19 & 21.0 \\
\hline \multicolumn{9}{|c|}{ Ever used Contraceptives } \\
\hline No & 18.56 & 19.0 & 19.27 & 18.0 & 19.09 & 19.0 & 20.97 & 21.0 \\
\hline Yes & 19.03 & 19.0 & 18.51 & 18.0 & 19.29 & 19.0 & 20.42 & 20.0 \\
\hline
\end{tabular}

\subsection{Kaplan Meier Graph}

The Kaplan Meier (KM) survival method is non-parametric technique for analyzing survival time data. The KM graph compares the survival times between two groups. The log-rank test is used to test the equality of survivor functions 
within groups. The KM survivor graphs for each of the selected background characteristics across NFHS rounds were analyzed. The graphs are shows below.

\subsection{NFHS-1}

The log rank test of survivor function indicates that survival probabilities are statistically different for rural and urban places of residence. The null hypothesis that the survivor probabilities for rural and urban are equal is rejected. Similarly the survival probabilities are statistically different among SC/ST and Other caste groups.

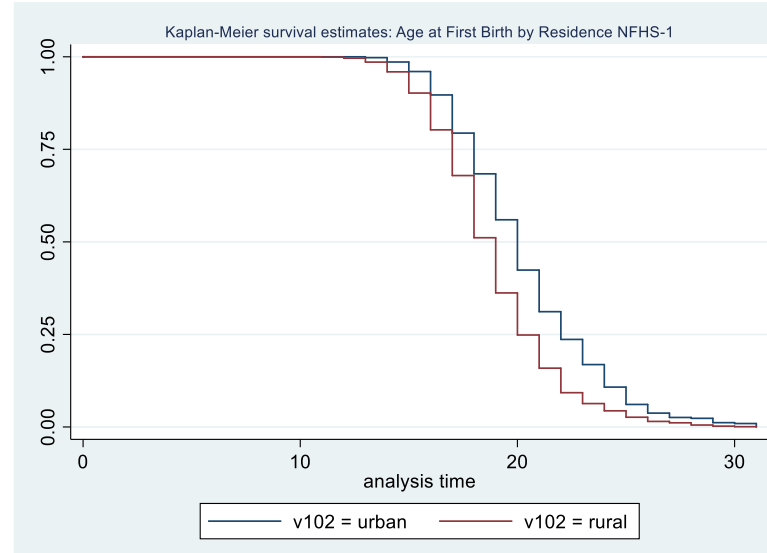

$\operatorname{chi} 2(1)=62.49 \quad \operatorname{Pr}>\operatorname{chi} 2=0.0000$

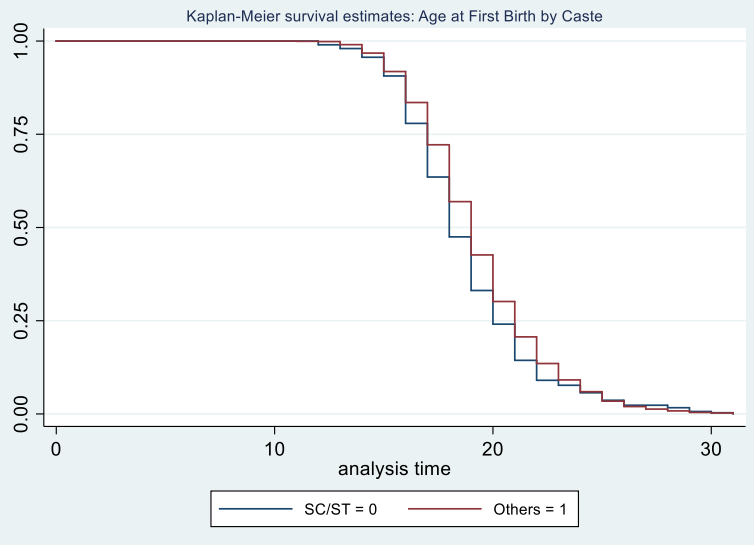

$\operatorname{chi} 2(1)=6.08 \quad \operatorname{Pr}>\operatorname{chi} 2=0.0137$

The null hypothesis was accepted for religious sub groups as the survivor probabilities were not statistically different among Hindus and Other religious groups. However, the survivor probabilities are statistically different among illiterates and literates.

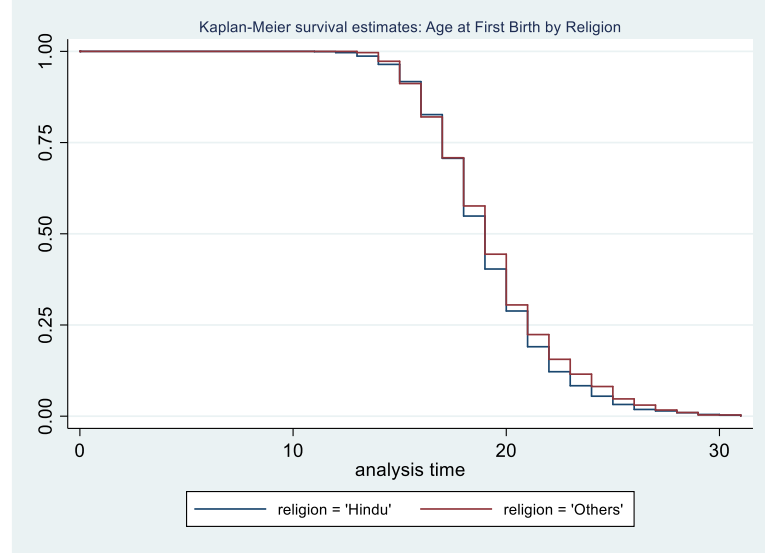

$\operatorname{chi} 2(1)=1.89 \quad \operatorname{Pr}>\operatorname{chi} 2=0.1691$

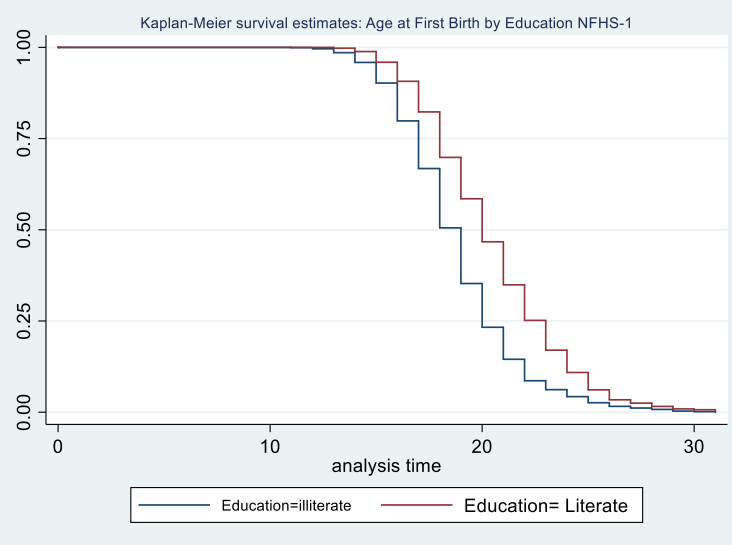

$\operatorname{chi} 2(1)=83.32 \quad$ Pr $>$ chi $2=\quad 0.0000$

The survivor probabilities are not statistically different in case of ever users of contraceptives and thus the null hypothesis of equality of survivor function was accepted. 

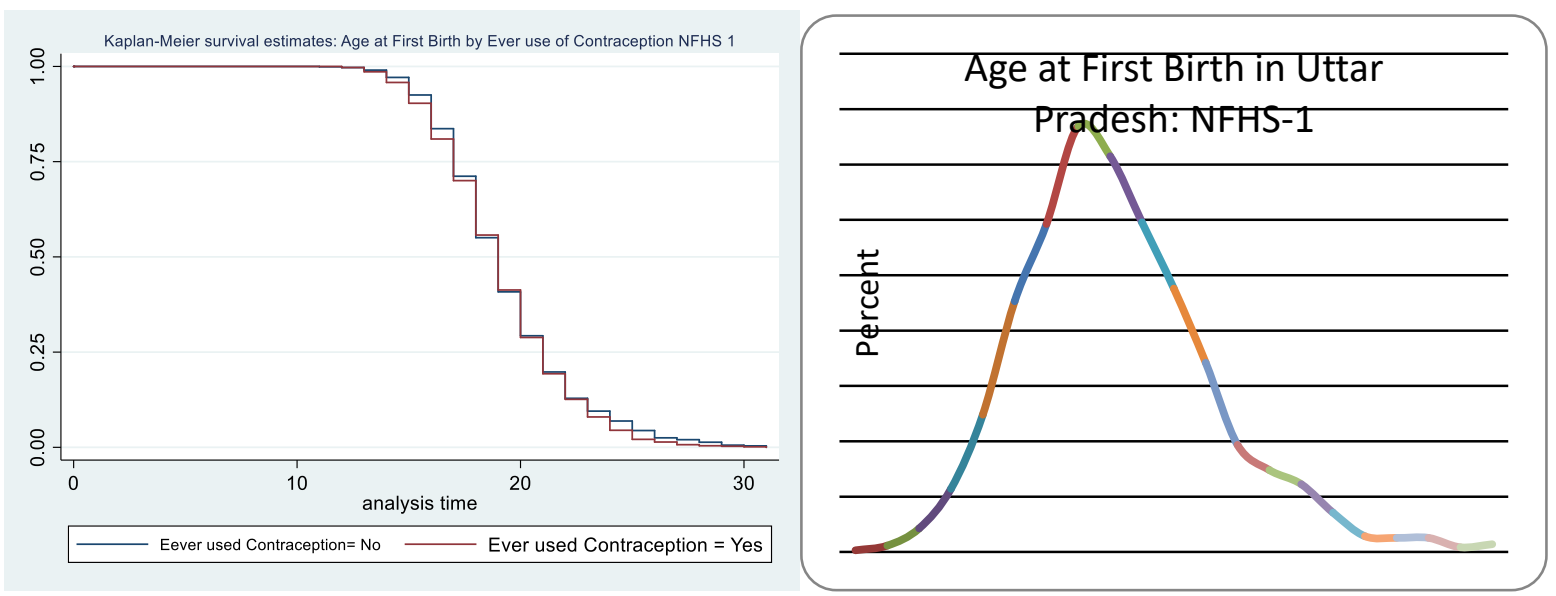

$$
\operatorname{chi} 2(1)=1.44 \quad \operatorname{Pr}>\operatorname{chi} 2=0.2303 \quad \mathrm{~N}=1755
$$

\subsection{NFHS-2}

The log rank test for equality of survivor function for the sub categories of the predictor variable shows that except for religion sub categories, all other predictors sub category survivor function were significantly statistically different. Details are shown in the graph below

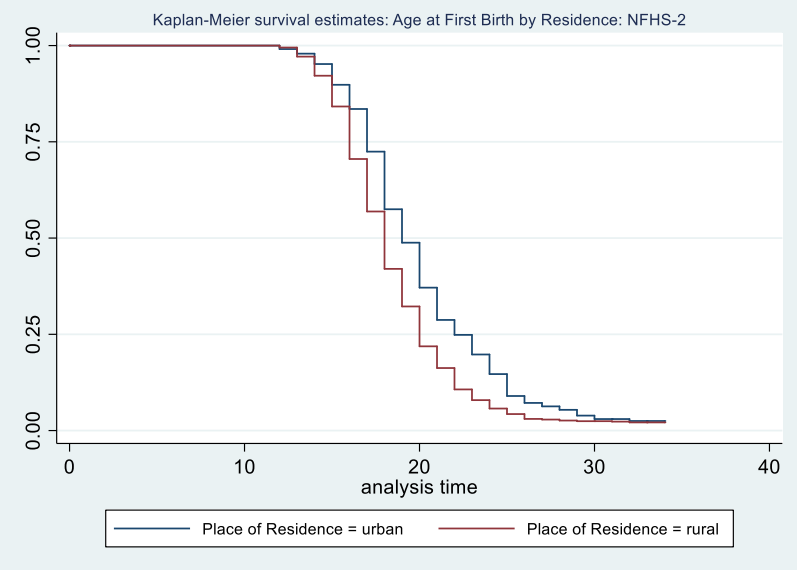

$\operatorname{chi} 2(1)=35.14 \quad \operatorname{Pr}>\operatorname{chi} 2=0.0000$

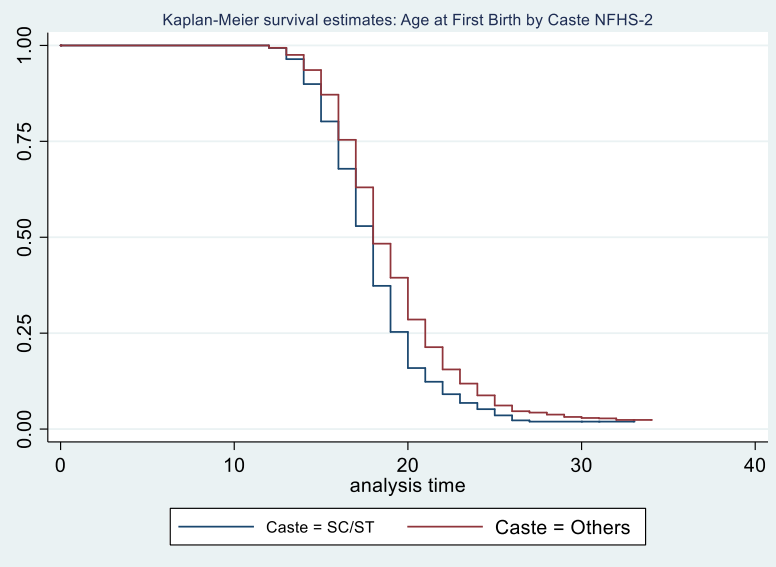

$\operatorname{chi} 2(1)=19.28$

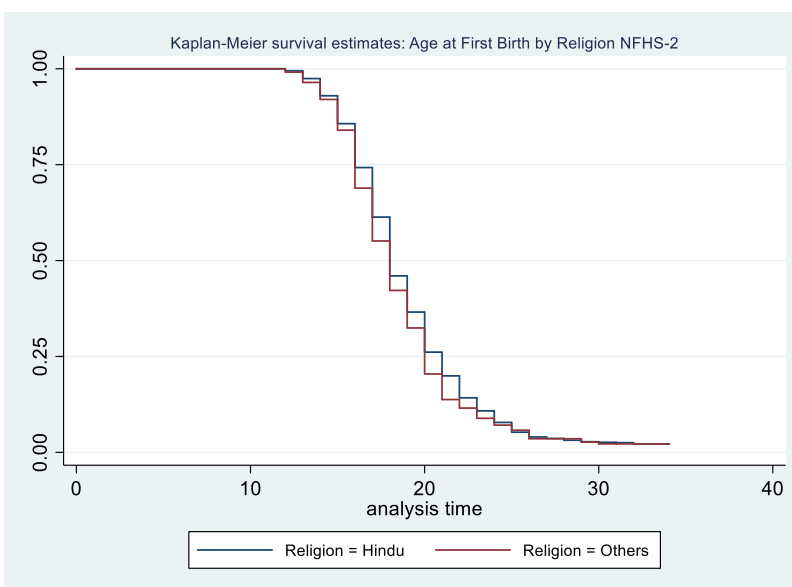

$\operatorname{chi} 2(1)=2.33 \quad \operatorname{Pr}>\operatorname{chi} 2=0.1272$

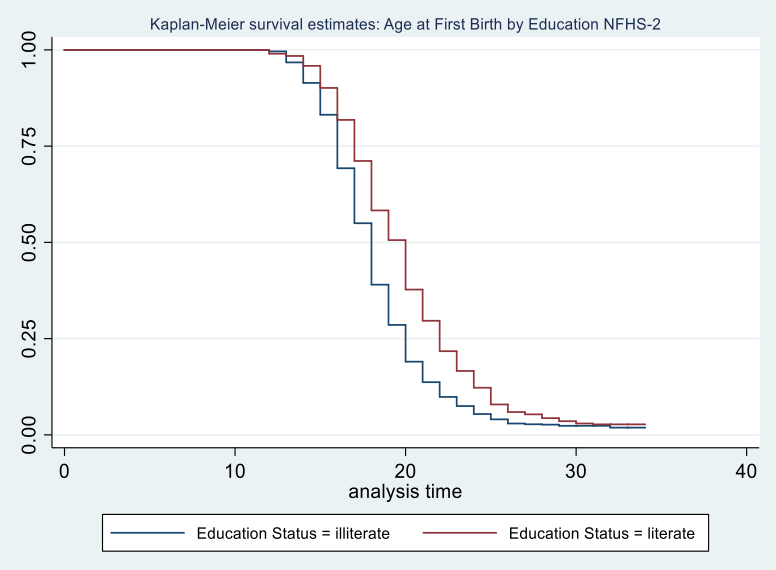

$\operatorname{chi} 2(1)=55.46 \quad \operatorname{Pr}>\operatorname{chi} 2=0.0000$ 

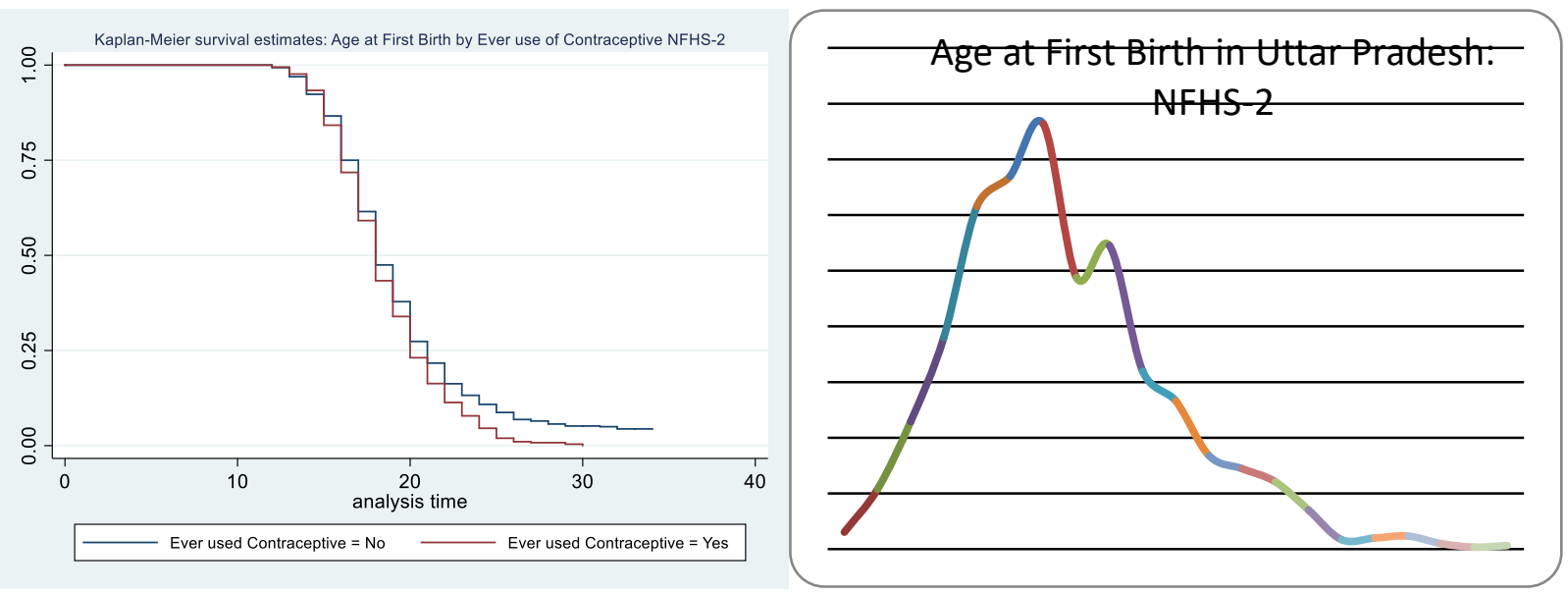

$\operatorname{ch} 2(1)=19.03 \quad \operatorname{Pr}>\operatorname{chi} 2=0.0000 \quad \mathrm{~N}=1486$

5.4 NFHS-3

The log rank test for equality of survivor function for the sub categories of the predictor variable shows that except for religion sub categories, all other predictors sub category survivor function were significantly statistically different. Details are shown in the graph below
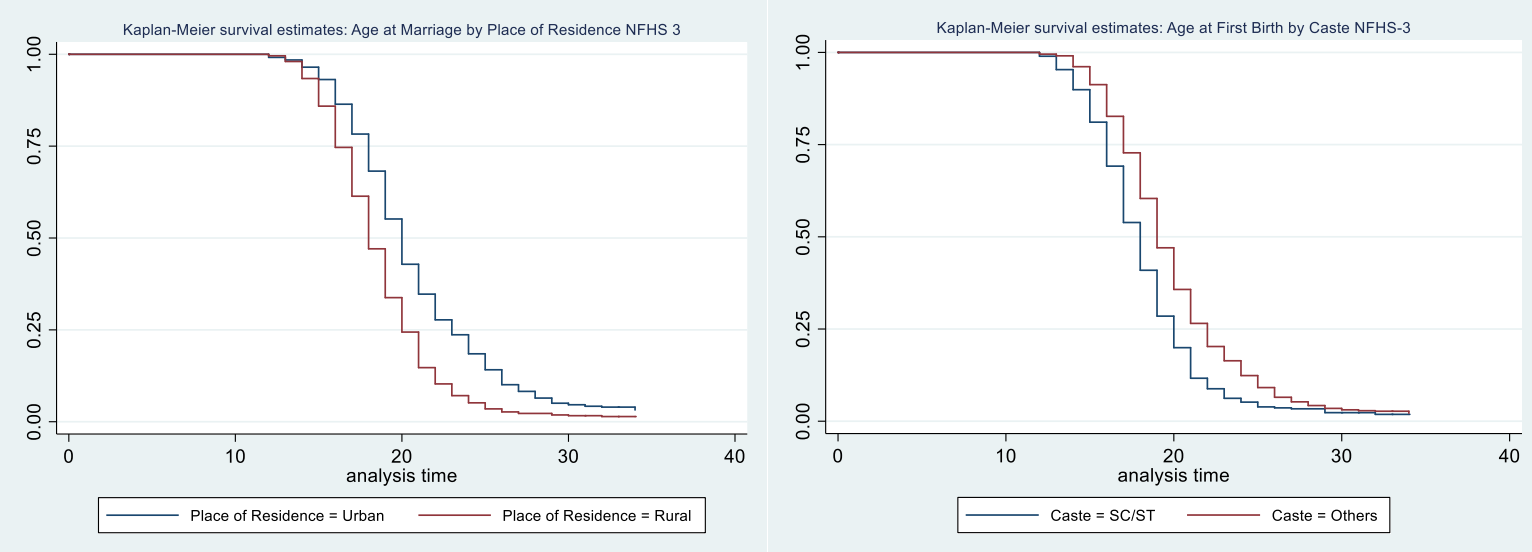

$\operatorname{chi} 2(1)=111.10 \quad \operatorname{Pr}>\operatorname{chi} 2=0.0000$

$$
\operatorname{chi} 2(1)=54.09 \quad \operatorname{Pr}>\operatorname{chi} 2=0.0000
$$

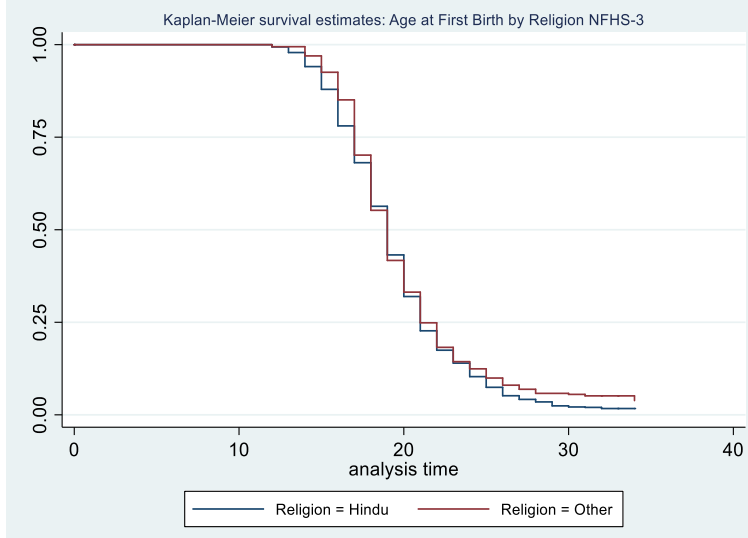

$\operatorname{chi} 2(1)=2.86 \quad \operatorname{Pr}>\operatorname{chi} 2=0.0908$

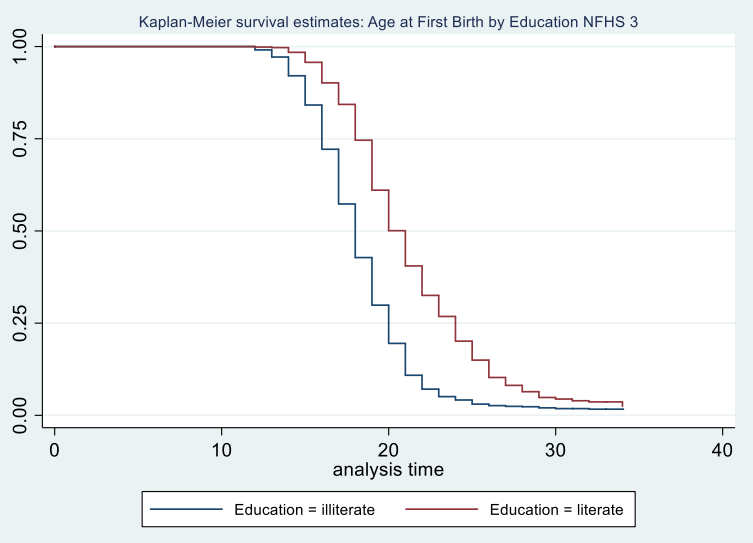

$\operatorname{chi} 2(1)=214.66 \quad \operatorname{Pr}>\operatorname{chi} 2=0.0000$ 

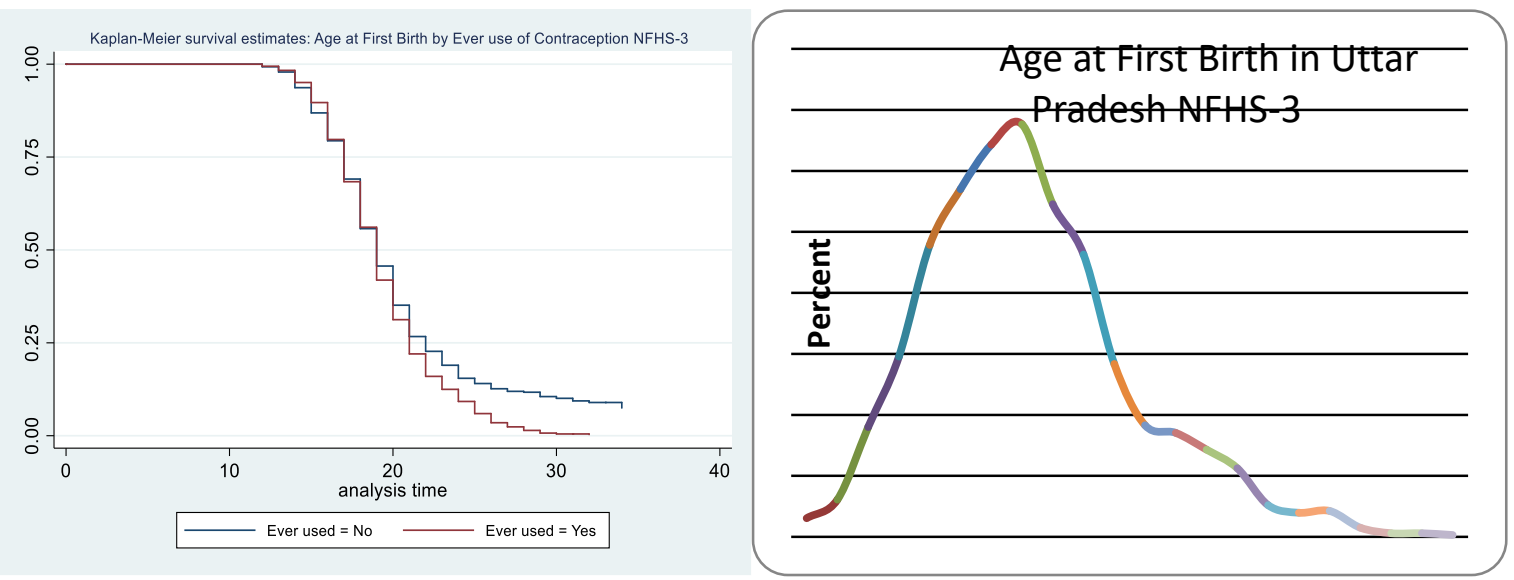

$$
\operatorname{chi} 2(1)=24.89 \quad \operatorname{Pr}>\operatorname{chi} 2=0.0000 \quad \mathrm{~N}=1641
$$

\subsection{NFHS -4}

The log rank test for equality of survivor function for the sub categories of the predictor variable shows that sub categories survivor function were significantly statistically different in case of all predictors. Details are shown in the graph below

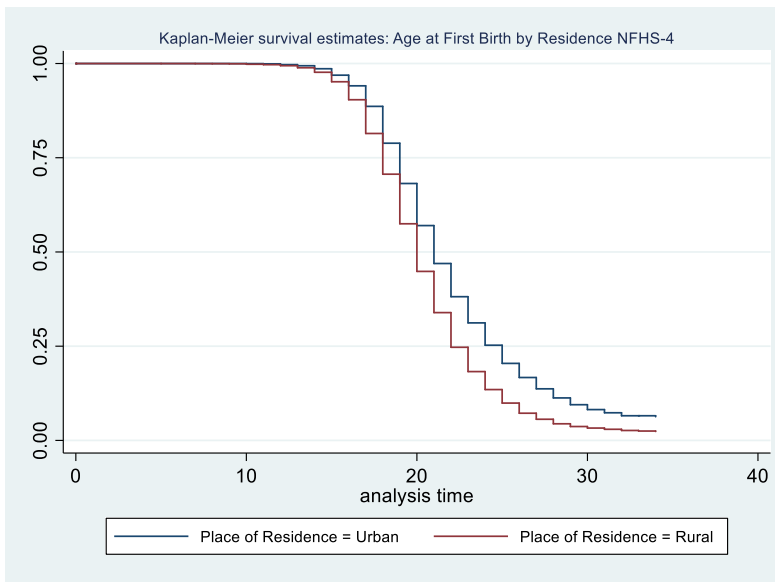

$\operatorname{chi} 2(1)=296.54 \quad \operatorname{Pr}>\operatorname{chi} 2=0.0000$

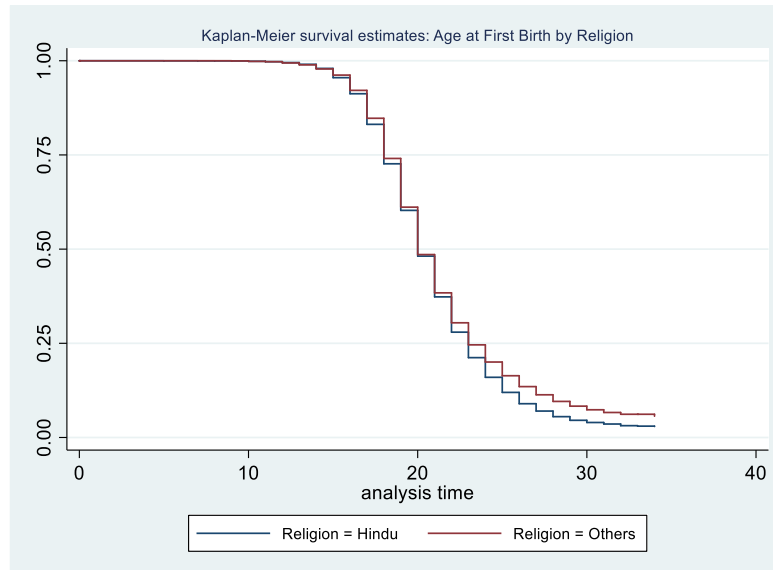

$\operatorname{chi} 2(1)=27.32$
$\operatorname{Pr}>$ chi $2=0.0000$

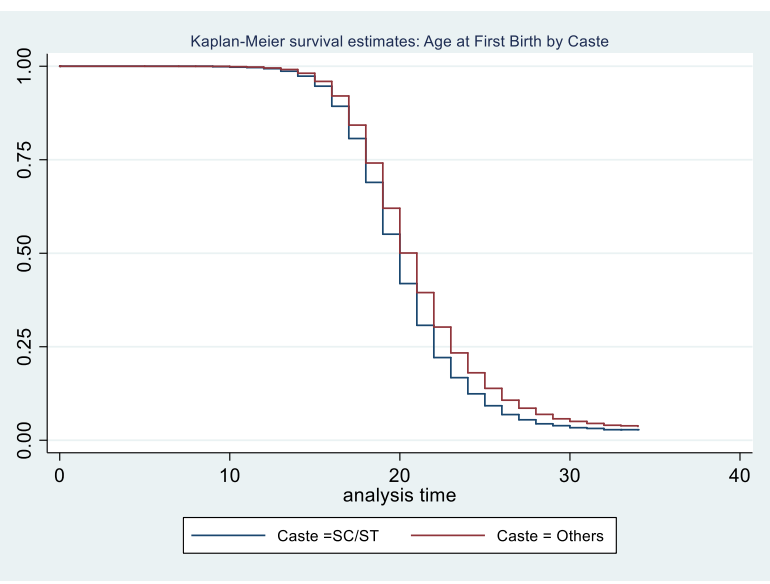

$\operatorname{chi} 2(1)=80.19 \quad \operatorname{Pr}>\operatorname{chi} 2=0.0000$

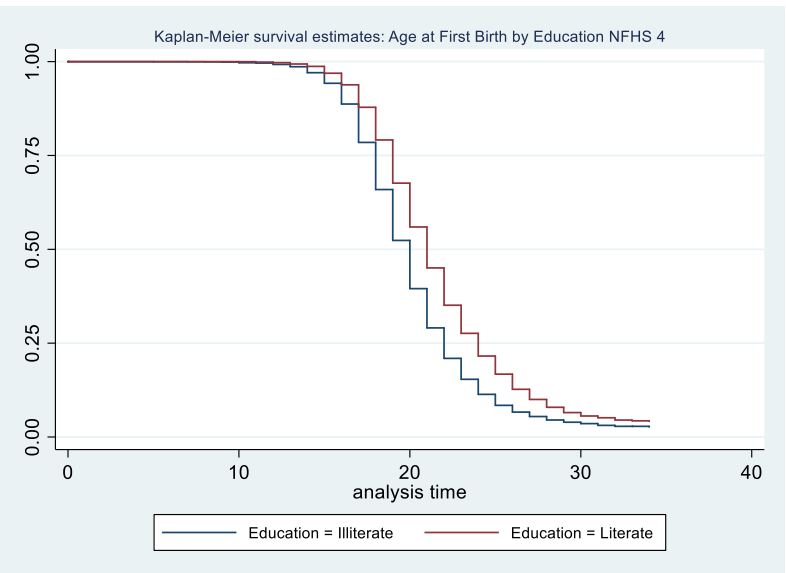

$\operatorname{chi} 2(1)=366.42 \quad$ Pr $>\operatorname{chi} 2=0.0000$ 

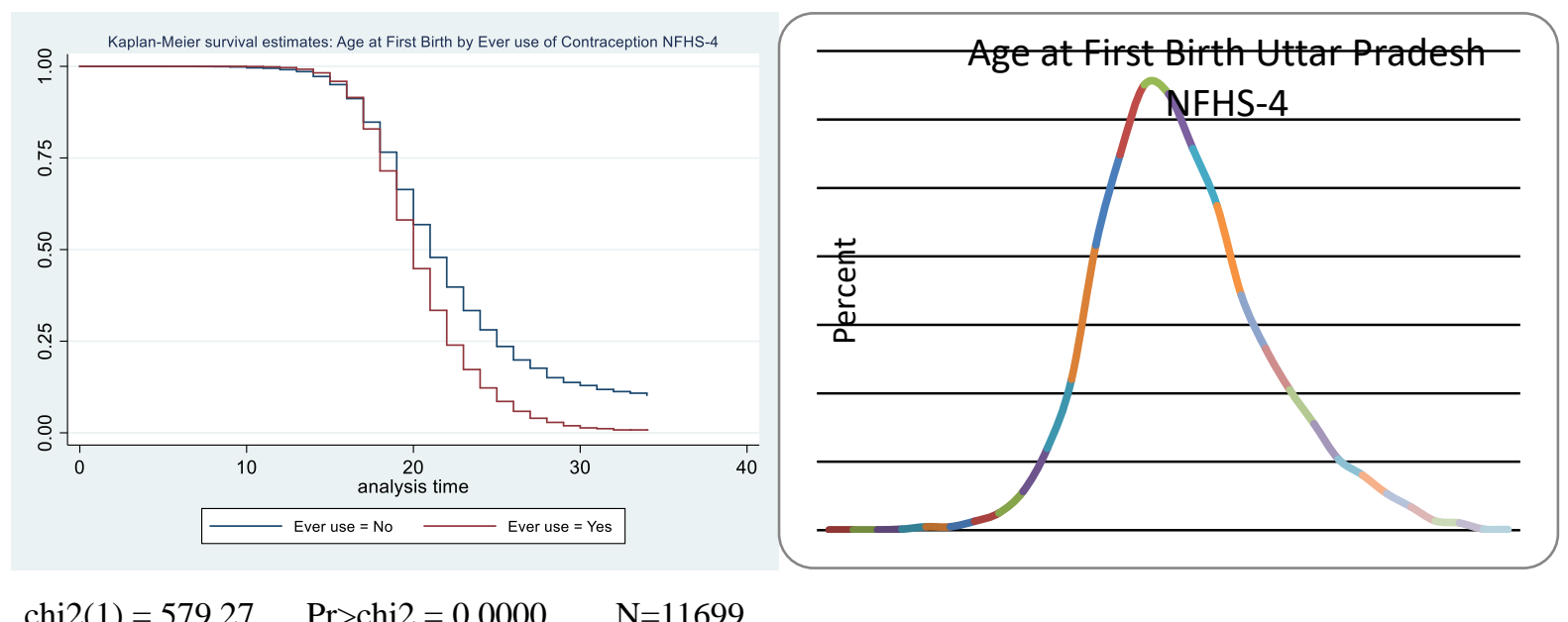

$$
\operatorname{chi} 2(1)=579.27 \quad \text { Pr }>\text { chi2 }=0.0000 \quad \mathrm{~N}=11699
$$

Annexure tables 2, 3, 4 \& 5 present the finding from the Cox Proportional Hazards model with constant baseline Hazard function. The proportionality assumption for each covariate under study was examined using Log-log plot. The place of residence, religion and the ever use of contraception categories were found to be non-proportional and ideally should have been dropped from the analysis, but in order to study the direction of their effects these variables were not omitted from the analysis.

Age at marriage is significant predictor across the NFHS data time points. The findings from the Cox model shown in table 2 to 5 suggests one year increase in age at marriage reduces the risk of first birth by $16 \%$ to $21 \%$ and is statistically highly significant. No significant difference in age at first birth by place of residence was observed across NFHS time points. Compared to Hindus, those belonging to 'Other' religious groups have $14 \%$ to $16 \%$ higher chance of having first birth early and are significant as shows by NFHS-1 \& NFHS-4 data. However, there is no significant difference in age at first birth by religion in the NFHS datasets from round- 2 \& round-3.

No significant difference in age at first birth by caste was observed in the findings from NFHS-1 \& 3 dataset as shown in the annexure table $2 \& 4$, however the findings from NFHS-2 data presented in annexure table 3 shows those belonging to other than SC/ST caste have 33 percent significantly higher risk of having age at first birth earlier than their counterparts, while the findings from NFHS-4 shown in annexure table-5 suggests those belonging to other than SC/ST castes have 7 percent significant lower risk of age at first birth compared to SC/ST sub caste.

Effect of education is more pronounced in the dataset from NFHS-3 (annex table-4). Literate women have 28 percent significant lower risk of lower ages at first birth compared to illiterates. Similarly, findings from NFHS-4 dataset (annex table-5) shows being literate reduced the risk of age at first birth by 5 percent and is significant compared to illiterate counterparts. Education did not significantly determine variations in age at first birth in NFHS-1 and NFHS-2 datasets.

Surprisingly, across NFHS data points the risk of first birth was significantly higher among ever users of contraception compared to non-users. As presented in annexure table- 2 to 5 the risk of first birth was higher among ever users of contraceptives by 35 percent (NFHS-1), 57 percent (NFHS-2), 133 percent (NFHS-3) and 88 percent (NFHS-4) respectively, compared to non-users. A surprising result with the status of contraceptive use by women may be due to the method adopted by their husbands. However, due to data limitations this may not be claimed precisely.

Annexure table 6, 7, 8 \& 9 below presents findings from the parametric survival model were-in the baseline hazard function for age at first birth follows the Weibull distribution. The study also captures unobserved heterogeneity in survival time by incorporating Gamma frailty. Frailty model is used to capture unobserved heterogeneity in the data. Firstly, women may be at differential risk of initiating the child bearing besides the age of women at first birth may be affected by the factors other than those that are not considered in the analysis. Some of these factors are unobservable. For example, the age at marriage significantly determines age at first birth in the Cox model shown above. However, there are many cultural considerations that determine age at marriage such as prevalence of dowry, socio-economic status of respondent's family, individual attributes such as beautifulness etc. which may be precisely incorporated in the model; thus, the use of frailty models.

As the parametric form is assigned to the baseline hazard function, the analysis was carried out using full set of covariates. The direction and propensity of the effect are shown in the annexure table 6 to 9 . Age at marriage across NFHS data points significantly determine age at first birth. The effects are even sharper compared to Cox model. The shape parameter ( $1 / \mathrm{p}$ value) being non zero justifies the use of parametric form for baseline hazard function. Similarly, the null hypothesis that the estimate of variance parameter being zero is rejected (as $\theta>0$ ), pointing towards unobserved 
heterogeneity in the data. The variance parameter $(\theta)$ across NFHS data points as shown in the table annexure 6 to 9 are 1.94 (NFHS-1), 2.78 (NFHS-2), 3.24 (NFHS-3) \& 2.91 (NFHS-4) respectively and are quite large. It is therefore parsimonious to use the Weibull parametric distribution with Gamma frailty rather than simple Cox Survival Model in the analysis.

\section{Conclusion}

The findings from NFHS data emanating from Uttar Pradesh suggests significant changes in the recent fertility patterns; significantly drifting away from the typical characterization of "too early too fast" fertility. Women not only are marrying late but are also postponing the age at first birth towards higher ages. This has significant implications towards fertility reduction and achieving the goal of replacement fertility. Age at marriage across NFHS data time points significantly determines age at first birth and has policy implications. The legal minimum age at marriage in the State may be increased from 18 years to 22 years for females and 25 years for males.

\section{References}

Bumpass, L. L., Rindfuss, R., \& Janosik, R. B. (1978). Age and marital status at first birth and the pace of subsequent fertility. Demography, 15(1), 75-86. https://doi.org/10.2307/2060491

IIPS. (1995). National Family Health Survey (MCH \& Family Planning), India 1992-93. Bombay, IIPS.

IIPS, and ORC Macro International. (2000). National Family Health Survey (NFHS-2), 1998-99, Mumbai India.

IIPS, and Macro International. (2007). National Family Health Survey (NFHS-3), 2005-06: India: Volume 1. Mumbai IIPS.

IIPS. (2017). National Family Health Survey (NFHS-4), 2015-16. IIPS, Mumbai, India.

Rajaretnam, T. (1990). How delaying marriage and spacing births contributes to population control: an explanation with illustrations. Journal of Family Welfare, 36, 3-13.

Rao, K. V., \& Balakrishnan, T., R. (1988). Age at first birth in Canada: a hazard model analysis. GENUS, 44, 53-72.

Teachman, D. J., \& Heckert, D. A. (1985). The declining significance of first birth timing. Demography, 22, $185-198$. https://doi.org/10.2307/2061177

Wienke, A. (2011). Frailty Models in Survival Analysis. Taylor and Francis Group, LLC, London, Newyork. https://doi.org/10.1201/9781420073911

Zabin, L., \& Kiragu, K. (1998). The health consequences of adolescent sexual and fertility behavior in sub-saharan Africa. Studies of Family Planning, 29, 210-232. https://doi.org/10.2307/172160 


\section{Annexure}

Table 2. Findings from Cox Survival Model: Age at First Birth NFHS-1

\begin{tabular}{|c|c|c|c|c|c|c|}
\hline & Hazard Ratio & Std. Err & $\mathrm{Z}$ & $\mathrm{P}>|\mathrm{z}|$ & \multicolumn{2}{|c|}{$\begin{array}{l}\text { [95\% Confidence } \\
\text { Interval] }\end{array}$} \\
\hline Age at Marriage & 0.82 & 0.01 & -21.06 & 0.00 & 0.80 & 0.83 \\
\hline \multicolumn{7}{|l|}{ Place of residence } \\
\hline Urban (Ref.) & 1.00 & -- & -- & -- & -- & -- \\
\hline Rural & 1.02 & 0.06 & 0.28 & 0.78 & 0.90 & 1.15 \\
\hline \multicolumn{7}{|l|}{ Religion } \\
\hline Hindu (Ref.) & 1.00 & -- & -- & -- & -- & -- \\
\hline Other & 1.16 & 0.08 & 2.15 & 0.03 & 1.01 & 1.32 \\
\hline \multicolumn{7}{|l|}{ Caste } \\
\hline SC/ST (Ref.) & 1.00 & -- & -- & -- & -- & -- \\
\hline Others & 1.05 & 0.07 & 0.68 & 0.50 & 0.92 & 1.19 \\
\hline \multicolumn{7}{|l|}{ Education } \\
\hline Illiterate (Ref.) & 1.00 & -- & -- & -- & -- & -- \\
\hline Literate & 0.84 & 0.08 & -1.82 & 0.07 & 0.70 & 1.01 \\
\hline \multicolumn{7}{|l|}{ Ever used Contraceptives } \\
\hline Never used (Ref.) & 1.00 & -- & -- & -- & -- & -- \\
\hline Used Any Method & 1.35 & 0.08 & 4.98 & 0.00 & 1.20 & 1.52 \\
\hline \multicolumn{7}{|l|}{ Interaction } \\
\hline literate x Never Used (Ref.) & 1.00 & -- & -- & -- & -- & -- \\
\hline literate x Used Any Method & 0.97 & 0.06 & -0.48 & 0.63 & 0.86 & 1.09 \\
\hline
\end{tabular}

Table 3. Findings from Cox Survival Model: Age at First Birth NFHS-2

\begin{tabular}{|c|c|c|c|c|c|c|}
\hline \multirow[b]{2}{*}{ Age at Marriage } & \multirow{2}{*}{$\begin{array}{c}\text { Hazard Ratio } \\
0.84\end{array}$} & \multirow{2}{*}{$\begin{array}{c}\text { Std. Err } \\
0.01\end{array}$} & \multirow{2}{*}{$\begin{array}{c}Z \\
-15.74\end{array}$} & \multirow{2}{*}{$\begin{array}{l}\mathrm{P}>|\mathrm{z}| \\
0.00\end{array}$} & \multicolumn{2}{|c|}{$\begin{array}{l}\text { [95\% Confidence } \\
\text { Interval] }\end{array}$} \\
\hline & & & & & 0.82 & 0.86 \\
\hline \multicolumn{7}{|l|}{ Place of residence } \\
\hline Urban (Ref.) & 1.00 & -- & -- & -- & -- & -- \\
\hline Rural & 0.98 & 0.07 & -0.33 & 0.75 & 0.85 & 1.13 \\
\hline \multicolumn{7}{|l|}{ Religion } \\
\hline Hindu (Ref.) & 1.00 & -- & -- & -- & -- & -- \\
\hline Other & 0.95 & 0.06 & -0.76 & 0.45 & 0.83 & 1.08 \\
\hline \multicolumn{7}{|l|}{ Caste } \\
\hline SC/ST (Ref.) & 1.00 & -- & -- & -- & -- & -- \\
\hline Others & 1.33 & 0.11 & 3.63 & 0.00 & 1.14 & 1.55 \\
\hline \multicolumn{7}{|l|}{ Education } \\
\hline Illiterate (Ref.) & 1.00 & -- & -- & -- & -- & -- \\
\hline Literate & 0.90 & 0.06 & -1.73 & 0.08 & 0.79 & 1.01 \\
\hline \multicolumn{7}{|c|}{ Ever used Contraceptives } \\
\hline No (Ref.) & 1.00 & -- & -- & -- & -- & -- \\
\hline Yes & 1.57 & 0.09 & 7.83 & 0.00 & 1.40 & 1.76 \\
\hline
\end{tabular}

Table 4. Findings from Cox Survival Model: Age at First Birth NFHS-3

\begin{tabular}{lcccccc}
\hline & Hazard Ratio & Std. Err & $\mathrm{Z}$ & $\mathrm{P}>|\mathrm{z}|$ & $\begin{array}{c}{[95 \%} \\
\text { Confidence } \\
\text { Interval] }\end{array}$ \\
\hline Age at Marriage & & & & & \multicolumn{3}{c}{0.78} & 0.81 \\
Place of residence & 0.79 & 0.01 & -24.62 & 0.00 & 0.78 & -- \\
$\quad$ Urban (Ref.) & 1.00 & -- & -- & -- & -- & 1.03 \\
$\quad$ Rural & 0.92 & 0.05 & -1.50 & 0.13 & 0.82 & \\
Religion & & & & & &
\end{tabular}




\begin{tabular}{lcccccc}
$\quad$ Hindu (Ref.) & 1.00 & -- & -- & -- & -- & -- \\
$\quad$ Other & 1.06 & 0.07 & 0.80 & 0.42 & 0.92 & 1.20 \\
$\quad$ Caste & & & & & & \\
$\quad$ SC/ST (Ref.) & 1.00 & -- & -- & -- & -- & -- \\
$\quad$ Others & 1.00 & 0.06 & -0.01 & 0.99 & 0.88 & 1.13 \\
$\quad \begin{array}{l}\text { Education } \\
\quad \text { Illiterate (Ref.) }\end{array}$ & & & & & & \\
$\quad$ Literate & 1.00 & -- & -- & -- & -- & -- \\
$\quad \begin{array}{l}\text { Ever used Contraceptives } \\
\quad \text { No (Ref.) }\end{array}$ & 0.72 & 0.04 & -5.44 & 0.00 & 0.64 & 0.81 \\
$\quad$ Yes & 1.00 & -- & -- & -- & -- & -- \\
$\quad$ & 2.33 & 0.16 & 12.41 & 0.00 & 2.04 & 2.66 \\
\hline
\end{tabular}

Table 5. Findings from Cox Survival Model: Age at First Birth NFHS-4

\begin{tabular}{|c|c|c|c|c|c|c|}
\hline \multirow[b]{2}{*}{ Age at Marriage } & \multirow{2}{*}{$\begin{array}{c}\text { Hazard Ratio } \\
0.84\end{array}$} & \multirow{2}{*}{$\begin{array}{c}\text { Std. Err } \\
0.00\end{array}$} & \multirow{2}{*}{$\begin{array}{c}Z \\
-69.03\end{array}$} & \multirow{2}{*}{$\begin{array}{l}\mathrm{P}>|\mathrm{z}| \\
0.00\end{array}$} & \multicolumn{2}{|c|}{$\begin{array}{c}{[95 \%} \\
\text { Confidence } \\
\text { Interval] } \\
\end{array}$} \\
\hline & & & & & 0.84 & 0.85 \\
\hline \multicolumn{7}{|l|}{ Place of residence } \\
\hline Urban (Ref.) & 1.00 & -- & -- & -- & -- & -- \\
\hline Rural & 1.02 & 0.02 & 1.02 & 0.31 & 0.98 & 1.07 \\
\hline \multicolumn{7}{|l|}{ Religion } \\
\hline Hindu (Ref.) & 1.00 & -- & -- & -- & -- & -- \\
\hline Other & 1.14 & 0.03 & 5.09 & 0.00 & 1.08 & 1.20 \\
\hline \multicolumn{7}{|l|}{ Caste } \\
\hline SC/ST (Ref.) & 1.00 & -- & -- & -- & -- & -- \\
\hline Others & 0.93 & 0.02 & -3.04 & 0.00 & 0.89 & 0.98 \\
\hline \multicolumn{7}{|l|}{ Education } \\
\hline Illiterate (Ref.) & 1.00 & -- & -- & -- & -- & -- \\
\hline Literate & 0.95 & 0.02 & -2.50 & 0.01 & 0.91 & 0.99 \\
\hline \multicolumn{7}{|c|}{ Ever used Contraceptives } \\
\hline No (Ref.) & 1.00 & -- & -- & -- & -- & -- \\
\hline Yes & 1.88 & 0.04 & 27.49 & 0.00 & 1.80 & 1.97 \\
\hline
\end{tabular}

Table 6. Parametric Cox Survival Model with Weibull distribution and Gamma Frailty: Age at First Birth NFHS-1

\begin{tabular}{|c|c|c|c|c|c|c|}
\hline & Hazard Ratio & Std. Err & $\mathrm{Z}$ & $\mathrm{P}>|\mathrm{z}|$ & \multicolumn{2}{|c|}{$\begin{array}{l}\text { [95\% Confidence } \\
\text { Interval] }\end{array}$} \\
\hline Age at Marriage & 0.40 & 0.02 & -19.21 & 0.00 & 0.36 & 0.43 \\
\hline \multicolumn{7}{|l|}{ Place of residence } \\
\hline Urban (Ref.) & 1.00 & -- & -- & -- & -- & -- \\
\hline Rural & 0.98 & 0.13 & -0.19 & 0.85 & 0.76 & 1.26 \\
\hline \multicolumn{7}{|l|}{ Religion } \\
\hline Hindu (Ref.) & 1.00 & -- & -- & -- & -- & -- \\
\hline Other & 1.48 & 0.21 & 2.74 & 0.01 & 1.12 & 1.96 \\
\hline \multicolumn{7}{|l|}{ Caste } \\
\hline SC/ST (Ref.) & 1.00 & -- & -- & -- & -- & -- \\
\hline Others & 0.86 & 0.12 & -1.04 & 0.30 & 0.65 & 1.14 \\
\hline \multicolumn{7}{|c|}{ Ever used Contraceptives } \\
\hline No & 1.00 & -- & -- & -- & -- & -- \\
\hline Yes & 1.42 & 0.15 & 3.20 & 0.00 & 1.14 & 1.75 \\
\hline _cons & 0.00 & 0.00 & -24.84 & 0.00 & 0.00 & 0.00 \\
\hline //ln_p & 3.11 & 0.04 & 74.19 & 0.00 & 3.03 & 3.20 \\
\hline /Intheta & 0.66 & 0.07 & 9.22 & 0.00 & 0.52 & 0.80 \\
\hline $\mathrm{p}$ & 22.49 & 0.94 & & & 20.71 & 24.41 \\
\hline $1 / \mathrm{p}$ & 0.04 & 0.00 & & & 0.04 & 0.05 \\
\hline theta & 1.94 & 0.14 & & & 1.68 & 2.23 \\
\hline
\end{tabular}


Table 7. Parametric Cox Survival Model with Weibull distribution and Gamma Frailty: Age at First Birth NFHS-2

\begin{tabular}{|c|c|c|c|c|c|c|}
\hline & Hazard Ratio & Std. Err & $\mathrm{Z}$ & $\mathrm{P}>|\mathrm{z}|$ & \multicolumn{2}{|c|}{$\begin{array}{l}\text { [95\% Confidence } \\
\text { Interval] }\end{array}$} \\
\hline Age at Marriage & 0.36 & 0.02 & -17.17 & 0.00 & 0.32 & 0.41 \\
\hline \multicolumn{7}{|l|}{ Place of residence } \\
\hline Urban (Ref.) & 1.00 & -- & -- & -- & -- & -- \\
\hline Rural & 0.71 & 0.13 & -1.90 & 0.06 & 0.50 & 1.01 \\
\hline \multicolumn{7}{|l|}{ Religion } \\
\hline Hindu (Ref.) & 1.00 & -- & -- & & -- & -- \\
\hline Other & 0.90 & 0.15 & -0.60 & 0.55 & 0.65 & 1.25 \\
\hline \multicolumn{7}{|l|}{ Caste } \\
\hline SC/ST (Ref.) & 1.00 & -- & -- & -- & -- & -- \\
\hline Others & 1.79 & 0.33 & 3.12 & 0.00 & 1.24 & 2.59 \\
\hline \multicolumn{7}{|l|}{ Education Status } \\
\hline Illiterate & 1.00 & -- & -- & -- & -- & -- \\
\hline Literate & 0.94 & 0.15 & -0.40 & 0.69 & 0.69 & 1.28 \\
\hline \multicolumn{7}{|c|}{ Ever used Contraceptives } \\
\hline No & 1.00 & -- & -- & -- & -- & -- \\
\hline Yes & 1.79 & 0.24 & 4.26 & 0.00 & 1.37 & 2.34 \\
\hline _cons & 0.00 & 0.00 & -21.59 & 0.00 & 0.00 & 0.00 \\
\hline //ln_p & 3.10 & 0.05 & 64.39 & 0.00 & 3.00 & 3.19 \\
\hline /lntheta & 1.02 & 0.07 & 14.13 & 0.00 & 0.88 & 1.17 \\
\hline $\mathrm{p}$ & 22.16 & 1.07 & & & 20.16 & 24.35 \\
\hline $1 / \mathrm{p}$ & 0.05 & 0.00 & & & 0.04 & 0.05 \\
\hline theta & 2.78 & 0.20 & & & 2.42 & 3.21 \\
\hline
\end{tabular}

Table 8. Parametric Cox Survival Model with Weibull distribution and Gamma Frailty: Age at First Birth NFHS-4

\begin{tabular}{|c|c|c|c|c|c|c|}
\hline \multirow{2}{*}{ Age at Marriage } & \multirow{2}{*}{$\begin{array}{c}\begin{array}{c}\text { Hazard } \\
\text { Ratio }\end{array} \\
0.27\end{array}$} & \multirow{2}{*}{$\begin{array}{c}\text { Std. Err } \\
0.01\end{array}$} & \multirow{2}{*}{$\begin{array}{c}\mathrm{Z} \\
-55.10\end{array}$} & \multirow{2}{*}{$\begin{array}{l}\mathrm{P}>|\mathrm{z}| \\
0.00\end{array}$} & \multicolumn{2}{|c|}{$\begin{array}{c}\text { [95\% Confidence } \\
\text { Interval] } \\
\end{array}$} \\
\hline & & & & & 0.25 & 0.28 \\
\hline \multicolumn{7}{|l|}{ Place of residence } \\
\hline Urban (Ref.) & 1.00 & -- & -- & -- & -- & -- \\
\hline Rural & 0.81 & 0.04 & -3.96 & 0.00 & 0.72 & 0.90 \\
\hline \multicolumn{7}{|l|}{ Religion } \\
\hline Hindu (Ref.) & 1.00 & -- & -- & -- & -- & -- \\
\hline Other & 1.48 & 0.09 & 6.28 & 0.00 & 1.31 & 1.67 \\
\hline \multicolumn{7}{|l|}{ Caste } \\
\hline SC/ST (Ref.) & 1.00 & -- & -- & -- & -- & -- \\
\hline Others & 0.88 & 0.05 & -2.12 & 0.03 & 0.79 & 0.99 \\
\hline \multicolumn{7}{|l|}{ Education Status } \\
\hline Illiterate & 1.00 & -- & -- & -- & -- & -- \\
\hline Literate & 0.94 & 0.05 & -1.19 & 0.23 & 0.85 & 1.04 \\
\hline \multicolumn{7}{|c|}{ Ever used Contraceptives } \\
\hline No & 1.00 & -- & -- & -- & -- & -- \\
\hline Yes & 1.66 & 0.09 & 9.05 & 0.00 & 1.49 & 1.86 \\
\hline _cons & 0.00 & 0.00 & -64.98 & 0.00 & 0.00 & 0.00 \\
\hline$/ \operatorname{ln\_ p}$ & 3.44 & 0.02 & 213.65 & 0.00 & 3.41 & 3.47 \\
\hline /lntheta & 1.07 & 0.02 & 44.96 & 0.00 & 1.02 & 1.11 \\
\hline $\mathrm{p}$ & 31.08 & 0.50 & & & 30.12 & 32.08 \\
\hline $1 / \mathrm{p}$ & 0.03 & 0.00 & & & 0.03 & 0.03 \\
\hline theta & 2.91 & 0.07 & & & 2.78 & 3.05 \\
\hline
\end{tabular}

Table 9. Parametric Cox Survival Model with Weibull distribution and Gamma Frailty: Age at First Birth NFHS-3

\begin{tabular}{lcccccc}
\hline & $\begin{array}{c}\text { Hazard } \\
\text { Ratio }\end{array}$ & Std. Err & $\mathrm{Z}$ & $\mathrm{P}>|\mathrm{z}|$ & \multicolumn{2}{c}{$\begin{array}{c}{[95 \% \text { Confidence }} \\
\text { Interval }]\end{array}$} \\
\hline $\begin{array}{l}\text { Age at Marriage } \\
\begin{array}{c}\text { Place of residence } \\
\text { Urban (Ref.) }\end{array}\end{array}$ & 0.19 & 0.02 & -18.65 & 0.00 & 0.16 & 0.23 \\
& 1.00 & -- & -- & -- & -- & --
\end{tabular}




\begin{tabular}{|c|c|c|c|c|c|c|}
\hline Rural & 0.69 & 0.11 & -2.46 & 0.01 & 0.51 & 0.93 \\
\hline \multicolumn{7}{|l|}{ Religion } \\
\hline Hindu (Ref.) & 1.00 & -- & -- & -- & -- & -- \\
\hline Other & 1.32 & 0.22 & 1.63 & 0.10 & 0.95 & 1.84 \\
\hline \multicolumn{7}{|l|}{ Caste } \\
\hline SC/ST (Ref.) & 1.00 & -- & -- & -- & -- & -- \\
\hline Others & 0.66 & 0.12 & -2.35 & 0.02 & 0.46 & 0.93 \\
\hline \multicolumn{7}{|l|}{ Education Status } \\
\hline Illiterate & 1.00 & -- & -- & -- & -- & -- \\
\hline Literate & 0.44 & 0.07 & -5.04 & 0.00 & 0.32 & 0.60 \\
\hline \multicolumn{7}{|c|}{ Ever used Contraceptives } \\
\hline No & 1.00 & -- & -- & -- & -- & -- \\
\hline Yes & 2.14 & 0.36 & 4.46 & 0.00 & 1.53 & 2.99 \\
\hline _cons & 0.00 & 0.00 & -21.68 & 0.00 & 0.00 & 0.00 \\
\hline $\bar{l} / \mathrm{ln} \_\mathrm{p}$ & 3.52 & 0.05 & 72.85 & 0.00 & 3.43 & 3.62 \\
\hline /lntheta & 1.18 & 0.07 & 16.69 & 0.00 & 1.04 & 1.31 \\
\hline $\mathrm{p}$ & 33.93 & 1.64 & & & 30.86 & 37.30 \\
\hline $1 / p$ & 0.03 & 0.00 & & & 0.03 & 0.03 \\
\hline theta & 3.24 & 0.23 & & & 2.82 & 3.72 \\
\hline
\end{tabular}

\section{Copyrights}

Copyright for this article is retained by the author(s), with first publication rights granted to the journal.

This is an open-access article distributed under the terms and conditions of the Creative Commons Attribution license (http://creativecommons.org/licenses/by/4.0/). 